\title{
Assessment of english oak (Quercus robur L.) growth in varied soil-substrate conditions of reclaimed Piaseczno sulfur mine dump
}

\author{
Marcin Pietrzykowski $\bowtie$, Wojciech Krzaklewski, Justyna Likus, Bartłomiej Woś \\ University of Agriculture in Krakow, Faculty of Forestry, al. 29 Listopada 46, 31-425 Kraków, Poland, \\ phone: +48 1266250 83, e-mail: rlpietrz@cyf-kr.edu.pl
}

\begin{abstract}
This study presents selected tree stand features and stand productivity of the English oak (Quercus robur L.) growing in the conditions of a reclaimed external dump of Piaseczno sulfur mine in Tarnobrzeg mining area. Following 40 years of growth in the dump, the oak trees reached first and second bonitation class and good growth parameters. The oak obtained the highest stand volume and basal area on sandy soils and loamy-sand substrates. A significant negative correlation between high clay content in soil cores and tree stand parameters was observed, indicating unfavourable impact on tree growth. The results confirmed the usefulness of the English oak as the main (target) species in the conditions of sulfur dumps, and the suitability of its introduction with preliminary identification of micro-habitat differentiation.
\end{abstract}

\section{KeY WORDS}

afforestation, clays, mine soils, target species, tree stand

\section{INTRODUCTION}

Forest tree species in post-mining areas are introduced to techno soils whose properties are different from the soils in natural forest habitats (Pietrzykowski et al. 2010). This is manifested, among others, by unfavourable air and water conditions, drastic changes in $\mathrm{pH}$, deficient and disturbed quantitative relations of nutrients and, above all, by lack of soil organic matter (SOM). Hence, the selection of species composition and appropriate method of afforestation and tree species adaptation to emerging habitats are important problems in forest reclaim treatment (Pietrzykowski et al. 2010).
The reclaim treatment involves three afforestation strategies (Krzaklewski 2009): the so-called pioneer species method, the target (climax) and the biodynamic methods. The pioneer species method refers to the process of succession and pioneer crop forests (Krzaklewski 2009; Pietrzykowski 2014). Pioneer species are responsible for preparing the habitat for more demanding target species (Pietrzykowski 2014). According to popularly held opinions, the first species to appear in, for instance, post-natural disaster areas or post-agricultural fallow lands are photophilous species, insensitive to temperature fluctuations, with low habitat requirements - the so-called pioneer species. It is only under their cover 
that sensitive, climax species grow to form target stands (Jaworski 2011). The target species method may be classified as direct introduction of the so-called climax species following intensive agro-technological cultivation (Bender 1995). The biodynamic method involves the use of both the species with phytomelioration functions, most commonly of the alders (Alnus genus), as well as the target species (Krzaklewski 2009).

The oaks, especially the English oak and the red oak, were used in afforestation of post-mining areas in Poland as the target species with high stand productivity (Greszta and Morawski 1972; Krzaklewski 2009). An example of successful afforestation involving the oak is the reclaimed internal dump of Kazimierz open-cast mine (Konin-Turek lignite basin) (Gilewska 2010). The English oak was also introduced to the reclaimed dump of Turów lignite mine (Nietrzeba-Marcinonis 2007) and to the external dump of Turek Adamow lignite mine (Pietrzykowski et al. 2012), where it now has an over $19 \%$ share in the species composition of forest stands.

The study assesses the growth of the English oak introduced 40 years ago as the target species on Piaseczno sulfur open-cast mine dump. The assessment was made taking into account different soil substrates.

\section{StudY SITE}

The assessed oak stands were introduced from 1967-1974 to the external dump of Piaseczno open-cast sulfur mine, located in the area of Tarnobrzeg in the valley of the Vistula river ( $\mathrm{N} 50$ 33.622 E 21 34.185). This area has an average annual temperature of $7^{\circ} \mathrm{C}$, an average sum of precipitation of $650 \mathrm{~mm}$ and a growing season lasting 212 days (Woś 1999). The dump is composed mainly of Neogene clay deposits (pecten Krakowiec clays), quaternary sandy deposits and their mixtures resulting from indiscriminate development of overlay (Skawina 1974; Ziemnicki 1980; Węgorek 2003). Soils developing from these substrates are considered anthropogenic with poorly developed profile of Ol-Ainan-Can horizons (Pietrzykowski et al. 2010). The $\mathrm{pH}$ of soil ranges from strongly acidic in the organic horizon ( $\mathrm{pH}$ in $\mathrm{H}_{2} \mathrm{O}$ averaging 5.1, 4.6 in $\mathrm{KCl})$ to weakly alkaline in the deeper horizons ( $\mathrm{pH}$ in $\mathrm{H}_{2} \mathrm{O}$ averaging 7.6, 7.4 in $\mathrm{KCl}$ ). The soil in the reclaimed dump was classified as post-mining sand dump soil (Pietrzykowski et al. 2010).
Sulfur mining in the Piaseczno mine began in 1961. The first stage of the reclamation process included levelling off the top section and making a dike with a height of approximately $0.5 \mathrm{~m}$ and securing the embankment in order to reduce water erosion. Several sets of seedlings with different proportions of tree and shrub species were selected for the afforestation of the area. The actual afforestation species composition often differed from the assumptions of the project due to problems with the availability of planting material (personal communication by A. Szpak, forest officer, Staszów forest inspectorate). Species composition and afforestation distribution plans, including the English oak, black alder, Scots pine, common larch, common birch, black locust, some biocenotic species and poplar cultivars, were based on general identification of lithology and relief of the facility and a map of vegetation developed by way of natural succession; they were made in the 1970s (Krzaklewski in Skawina 1974; Ziemnicki 1980). When planning afforestation, the following were taken into account: protective, phytomelioration and productive functions of individual species. The English oak was used as the target species. In Piaseczno sulfur mine dump, it grows in stands that currently occupy approximately 30 ha (forest management plan for Staszów forest inspectorate, 2002-2011).

\section{Methods}

In order to identify the lithological diversity of the dump cover and species composition of the stands, oneare, circular $(\mathrm{r}=5.64 \mathrm{~m})$ sample plots (total of 73) were designated in a regular grid of $50 \times 50 \mathrm{~m}$ squares. In 18 of them, the English oak appeared in the form of homogeneous patches. Soil augers were used to take samples up to the depth of $100 \mathrm{~cm}$ (one in the centre and four on the circumference of each plot), and differentiation of substrate types was assessed. Next, the thickness of the layers in individual substrates (parent rock substrate) in the soil core was measured (to the nearest $0.0 \mathrm{~cm}$ ) and calculated as a percentage. On this basis, three test groups were distinguished: Group P - where bedrock is made of sand with a lower proportion of clays (up to $15 \%$ ); Group Pi - where bedrock is made of sandy clay with a higher proportion of clays (from 15-90\%); Group I - where bedrock is made of clays with a slight admix- 
ture of sandy substrates (up to $10 \%$; Neogene clays and quaternary sands characteristic are described above in study sites section).

In the designated research plots, the diameter at breast height $(\mathrm{DBH})$ and height $(\mathrm{H})$ of all trees were measured and tree canopy cover was estimated (according to instruction of forest management 2011).

For stands in the plots grouped according to the above lithological criterion, values for the following parameters were calculated: density, that is, the number of trees per $1 \mathrm{ha}$, the average diameter at breast height $\left(\mathrm{DBH}_{\mathrm{av}}\right)$, the mean diameter at breast height $\left(\mathrm{DBH}_{\mathrm{m}}\right)$, basal area at breast height $(\mathrm{G})$, the average Lorey's height (HL), that is, height weighted against basal area at breast height; average height $(\mathrm{H})$, tree stand volume $(\mathrm{V})$, average increase in height $\left(\mathrm{Z}_{\mathrm{h}}\right)$ and average increase in diameter $\left(Z_{d}\right)$. The bonitation classes were determined based on the 'Tables of forest stand volume and growth' by Szymkiewicz (2001). The period of 40 years was taken as base age (forest management plan for Staszów forest inspectorate, 2002-2011).

The significance of differences in tree stand growth parameter mean values between substrate-soil groups (P, Pi, I) were analysed using Tukey's least significant differences test. Normality of distribution was checked with Kolmogorov-Smirnov test and homogeneity of variance with Levene's test. Subsequently, Pearson's correlation analysis was conducted for growth parameters and the percentage of clay and sand in the soil profile. The research hypotheses were tested with a probability at $p=0.05$. Calculations were performed using Statistica 10 (StatSoft Inc. 2011).

\section{Results}

The density of trees per stand averaged $846 \mathrm{pcs}$./ha for all 18 plots. In the case of particular groups of substrates, it was: $\mathrm{P}-940, \mathrm{Pi}-883$ and $\mathrm{I}-714$ pcs./ha. The $\mathrm{DBH}_{\mathrm{av}}$ for the entire dataset averaged $17.1 \mathrm{~cm}$, and for individual substrates $\mathrm{P}-17.8 ; \mathrm{Pi}-16.0$; and $\mathrm{I}-17.4 \mathrm{~cm}$, respectively. The $\mathrm{DBH}_{\mathrm{m}}$ for all the plots was $15.9 \mathrm{~cm}$. In group $\mathrm{P}$, the $\mathrm{DBH}_{\mathrm{m}}$ was 16.5 , in group $\mathrm{Pi}-14.7$, in group I $-16.6 \mathrm{~cm}$. The $G$ for all the plots was $17.4 \mathrm{~m}^{2} / \mathrm{ha}$, for $\mathrm{P}-22.9, \mathrm{Pi}-15.8$, and $\mathrm{I}-13.6 \mathrm{~m}^{2} / \mathrm{ha}$.

The HL for the whole oak group from all the plots totalled $16.6 \mathrm{~m}$. In P, it was $17.3 \mathrm{~m}$; while in the other groups, it was lower and amounted to 16.2 and $16.4 \mathrm{~m}$. There were no statistically significant differences between the values of the features mentioned above. The $\mathrm{H}$ in group $\mathrm{P}$ was $16.3 \mathrm{~m}$, and in group $\mathrm{Pi}-14.1 \mathrm{~m}$. In these two groups, the $\mathrm{H}$ difference was significant (tab. 1). In group I, H was 14.7 and did not significantly differ from groups $\mathrm{P}$ and $\mathrm{Pi}$.

The highest $\mathrm{V}$ was recorded in the group $\mathrm{P}$ $-175.7 \mathrm{~m}^{3} / \mathrm{ha}$, in groups of $\mathrm{Pi}$ and I and these values were much lower and amounted to $\mathrm{Pi}-113.5 \mathrm{~m}^{3} / \mathrm{ha}$, and I - $103.3 \mathrm{~m}^{3} / \mathrm{ha}$.

The average $Z_{h}$ for oak on the dump amounted to $0.41 \mathrm{~m} / \mathrm{yr}$. The breakdown into groups looks as follows: $\mathrm{P}-0.43, \mathrm{Pi}-0.40 \mathrm{~m} / \mathrm{yr}$, and $\mathrm{I}-0.41 \mathrm{~m} / \mathrm{yr}$.

The average $Z_{d}$ for oak was $0.40 \mathrm{~cm} / \mathrm{yr}$. In group $\mathrm{P}$ it was $0.41 \mathrm{~cm} / \mathrm{yr}, \mathrm{Pi}-0.37 \mathrm{~cm} / \mathrm{yr}$, and I $-0.42 \mathrm{~cm} / \mathrm{yr}$.

On research, plots in group $\mathrm{P}$ on sandy substrates, class I of growth bonitation prevailed; in group $\mathrm{Pi}$, it was class II; while group I was the most diverse

Table 1. Selected tree stand characteristics on Piaseczno sulphur mine dump divided into soil-substrate groups

\begin{tabular}{|l|c|c|c|c|c|c|c|c|}
\hline \multicolumn{1}{|c|}{ Group $^{*}$} & $\begin{array}{c}\mathrm{DBH}_{\mathrm{m}}^{* *} \\
{[\mathrm{~cm}]}\end{array}$ & $\begin{array}{c}\mathrm{G} \\
{\left[\mathrm{m}^{2} / \mathrm{ha}\right]}\end{array}$ & $\begin{array}{c}\mathrm{HL} \\
{[\mathrm{m}]}\end{array}$ & $\begin{array}{c}\mathrm{H} \\
{[\mathrm{m}]}\end{array}$ & $\begin{array}{c}\mathrm{Z}_{\mathrm{h}} \\
{[\mathrm{m} / \mathrm{yr}]}\end{array}$ & $\begin{array}{c}\mathrm{Z}_{\mathrm{d}} \\
{[\mathrm{cm} / \mathrm{yr}]}\end{array}$ & $\begin{array}{c}\mathrm{V} \\
{\left[\mathrm{m}^{3} / \mathrm{ha}\right]}\end{array}$ & $\begin{array}{c}\text { Bonitation } \\
\text { class }^{* * *}\end{array}$ \\
\hline Sands (S) & $16.5^{\mathrm{a}}$ & $22.9^{\mathrm{a}}$ & $17.3^{\mathrm{a}}$ & $16.3^{\mathrm{b}}$ & $0.43^{\mathrm{a}}$ & $0.41^{\mathrm{a}}$ & $176^{\mathrm{a}}$ & $\mathrm{I}-\mathrm{II}$ \\
\hline Sandy clays (Pi) & $14.7^{\mathrm{a}}$ & $15.8^{\mathrm{a}}$ & $16.2^{\mathrm{a}}$ & $14.1^{\mathrm{a}}$ & $0.40^{\mathrm{a}}$ & $0.37^{\mathrm{a}}$ & $114^{\mathrm{a}}$ & $\mathrm{I}-\mathrm{II}$ \\
\hline Clays (I) & $16.6^{\mathrm{a}}$ & $13.6^{\mathrm{a}}$ & $16.4^{\mathrm{a}}$ & $14.7^{\mathrm{a}}$ & $0.41^{\mathrm{a}}$ & $0.42^{\mathrm{a}}$ & $103^{\mathrm{a}}$ & $\mathrm{I}-\mathrm{III}$ \\
\hline
\end{tabular}

Explanations:

* groups of plots split up according to the thickness of the substrates described in Methods;

** $\mathrm{DBH}$ - mean diameter at breast height, etc. - symbols explained in Methods;

*** bonitation classes were determined based on 'Tables of forest stand abundance and growth' by Szymkiewicz, the range for the plots in the selected groups was provided; G - basal area at breast height; HL - average Lorey's height; H - average height;

$\mathrm{Z}_{\mathrm{h}}$ - average increase in height; $\mathrm{Z}_{\mathrm{d}}$ - average increase in diameter; $\mathrm{V}$ - tree stand volume;

a , b - indicate significant differences between mean values for soil-substrate groups of plots. 
because classes I, II and III were reported on various plots.

There was a positive correlation between the V, G, and the percentage of sandy substrates (correlation coefficient $r$ was 0.77 and 0.76 , respectively), and a negative correlation between the $\mathrm{G}$ and the percentage of clays $(\mathrm{r}=-0.50)$.

\section{DisCUSSION OF RESEARCH RESULTS}

In the habitat conditions of Piaseczno open-cast sulfur mine dump, the English oak reached a high bonitation trend (I and II, and III exceptionally on heavy Krakowiec clays). In natural conditions, the species obtains high bonitation in fertile and very fertile habitats, that is, in forests and mixed fresh and humid forests (forest sites fundamental for silviculture, 2003). The results confirm the accuracy of the habitat diagnosis according to forest management plan for Staszów forest inspectorate, 2002-2011, in which the dump sites were classified as a potential fresh mixed forest. Detailed habitat studies conducted on the dump using mine soil quality index, also on fragments made of a mixture of sands and clays (Pietrzykowski et al. 2010) indicate that they change to resemble forest habitats.

Good adaptation of the English oak in emerging habitats on reclaimed mining sites in Poland is also confirmed by other literature data. On the inner dump of Kazimierz open-cast after 5 years of growth, the success rate of the oak was assessed at $82 \%$, and after 23 years from the first inspection - at $74 \%$ (Gilewska 2010). Complete tree canopy cover was reported in the reclaimed Turów lignite mine dump 25 years after the introduction of afforestation with the English oak as the target species and alder serving as additional species (phytomelioration species) (Górecki and Nietrzeba-Marcinonis 2009). The reclaim treatment in Adamów lignite mine dump in Turek was equally successful; there also the percentage of the oak (currently the sessile oak and the English oak jointly account for over $19 \%$ in the afforestation of the dump) in the species composition was high (Pietrzykowski et al. 2012). Stähr (2003) found that the oak in Lusatian lignite mine district grows well in parts of dumps made of clay and loamy-sand tertiary substrates. As indicated by the growth parameters of the English oak, this species should grow well in forest habitats with substrates containing a significant proportion of clays (Modrzyński et al. 2006). However, in the conditions of the investigated dump, the oak displayed better growth parameters on fragments composed of mixtures of quaternary sands and Neogene clays compared to fragments made entirely of Neogene clays. Lower growth parameters of the oak on clay substrates may be explained by the fact that despite the relatively high abundance of nutrients, soils made of this substrate have unfavourable air and water properties ( $\mathrm{Pi}$ etrzykowski et al. 2010). This confirms the validity of the recommendations made years ago by expertise of Adamczyk and Maciaszek (1972) to mix sand and clay substrates at the dump construction phase. Although in the case of reclaimed land, the productive function is secondary to the protective and habitat-forming functions, the oak is a suitable target species in the investigated dump (Pietrzykowski et al. 2010).

\section{Conclusions}

1. The results indicate good growth parameters and usefulness of the English oak in conditions of emerging habitats on reclaimed Piaseczno sulfur mine dump;

2. The best growth conditions for the English oak occur on parts made of mixtures of quaternary sands and Neogene clays. This confirms the validity of the postulate that sandy substrates should be mixed with clay ones at the dump construction phase;

3. Poorer growth parameters of the oak on clay substrates may be explained by the fact that despite the considerable abundance of nutrients, soils composed of this substrate have probably worse air-water properties, but these have to be studied in the future.

\section{Acknowledgement}

The results were presented on 2nd international scientific conference: Forestry in the Mountains and Industrial Regions at 65th Anniversary of the Faculty of Forestry in Krakow, 22-23 September, 2014. 


\section{References}

Adamczyk B., Maciaszek W. 1972. Petrography and pedology characteristic, and selected aspects of technical and environmental reclamation of sulfur mine dump in Piaseczno. In: XIX Polish Science Meeting of Polish Soil Science Society: Soil environmental protection, Katowice-Kraków-Puławy, 372-381 (in Polish).

Bender J. 1995. Reclamation of post-mining areas in Poland. Zeszyty Problemowe Postępów Nauk Rolniczych, 418, 75-86 (in Polish).

Forest management plan for Staszów forest inspectorate 2002-2011. Biuro Urządzania Lasu i Geodezji Leśnej, Radom (in Polish).

Forest site fundamentals for silviculture. 2003. Załącznik do Zasad Hodowli i Użytkowania Lasu Wielofunkcyjnego. DGLP, Warszawa (in Polish).

Gilewska M. 2010. The forest reclamation of post mining area in Konin-Turek Lignite Basin. Zeszyty Naukowe Uniwersytetu Zielonogórskiego, Inżynieria Środowiska, 137 (17), 94-101 (in Polish).

Górecki R., Nietrzeba-Marcinonis J. 2009. Restoration of forest ecosystem, as the effect of reclamation treatments. In: Symposium: Natural Risks in Mining, Bogatynia, Poland, 246-256 (in Polish).

Greszta J., Morawski S. 1972. Reclamation of post-industrial sites. PWRiL, Warszawa (in Polish).

Instruction of forest management. 2003. CILP, Warszawa (in Polish).

Jaworski A. 2011. Silviculture, management methods, forest regeneration, reconstruction and transformation of forest stands. PWRiL, Warszawa (in Polish).

Krzaklewski W. 2009. Selected issues of forest reclamation. In.: Forestry in the mountain and industrial regions. Monograph published in 60 anniversary of foundation of Faculty of Forestry University of Agriculture in Krakow (ed.: J. Starzyk), Wydawnictwo Uniwersytetu Rolniczego w Krakowie, Kraków, 83-97 (in Polish).

Modrzyński J., Robakowski P., Zientarski J. 2006. Ecology. In: Oaks, Quercus robur L. Quercus petraea L. (ed.: W. Bugała), Bogucki Wydawnictwo Naukowe, Poznań, 411-590 (in Polish).
Nietrzeba-Marcinonis J. 2007. Influence of forest reclamation of post-mine sites on selected characteristic of initial soil exemplified on Turów S.A. Lignite Mine external dump. Ph. D. thesis, University of Zielona Góra (in Polish).

Pietrzykowski M., Krzaklewski W., Pająk. M., Socha J., Ochał W. 2010. Analysis and optimization of site classification methods and criterions for reclamation assessments exemplified on selected post-mine sites in Poland. Wydawnictwo Uniwersytetu Rolniczego w Krakowie, Kraków (in Polish).

Pietrzykowski M., Krzaklewski W., Woś B. 2012. The assessment of forest management on reclaimed sites of Lignite Mine Adamów, admitted to Forest Inspectorate Turek. In.: Post-mine sites in the Konin Region, 20.11.2012, County Museum in Konin, 43-52 (in Polish).

Pietrzykowski M. 2014. Soil quality index as a tool for Scots pine (Pinus sylvestris L.) monoculture conversion planning on afforested, reclaimed mine land. Journal of Forestry Research, 25 (1), 63-74.

Skawina T. 1974. Characteristic of reclamation activity on Piaseczno sulfur mine external dump. AGH, Kraków (in Polish).

StatSoft Inc. 2011. STATISTICA (data analysis software system), version 8.1 .

Stähr F. 2003. Interaktionen zwischen Boden und Bestockung auf Kippenstandorten des Niederlausitzer Braunkohlenrevieres am Beispiel der Rekultivierungsbaumarten Gemeine Kiefer, Gemeine Birke und Traubeneiche. $\mathrm{PhD}$, Technischen Universität Dresden (in German).

Szymkiewicz B. 2001. Tables of stand volume and increment for mostly important forest tree species species. PWRiL, Warsaw (in Polish).

Węgorek T. 2003. Changes in some properties of soil material and the development of phyto-cenoses on external dumping grounds of a sulfur mine resulting from target reclamation. Rozprawy Naukowe AR w Lublinie, 275 (in Polish).

Woś A. 1999. Climate in Poland. PWN, Warszawa (in Polish).

Ziemnicki S. 1980. Reclamation of open strip mine dump exemplified by Piaseczno. Problems of Industrial Regions. PWN, Warszawa (in Polish). 